\title{
Basal Cell Carcinoma
}

National Cancer Institute

\section{Source}

National Cancer Institute. Basal Cell Carcinoma. NCI Thesaurus. Code C156767.

A carcinoma involving the basal cells. 